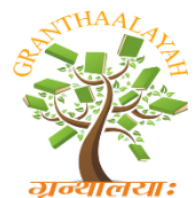

\author{
INTERNATIONAL JOURNAL OF RE
GRANTHAALAYAH \\ A knowledge Repository
}

Science

\title{
DETERMINATIONS OF SOME HEAVY METALS IN VEGETABLES CULTIVATED IN SOME VILLAGES IN DAMBOA, NORTH - EASTERN NIGERIA
}

\author{
Halima Bala Mohammed ${ }^{1}$, Gwana Adamu Mohammed *2, Kolo, Baba Gana ${ }^{3}$, Hamra \\ Abatcha Ahmed ${ }^{4}$, Kolo, Mu'azu Abdullahi Kofar Na'isa ${ }^{5}$, Abubakar Aliyu ${ }^{6}$ \\ ${ }^{1}$ Department of Basic Science and Technology, Mohamet Lawan College of Agriculture, \\ Maiduguri, Nigeria \\ ${ }^{2}$ Laboratory Unit, Department of Animal Health and Production Technology, Mohamet Lawan \\ College of Agriculture, Maiduguri, Nigeria \\ ${ }^{3}$ Department of Chemistry, Faculty of Science, University of Maiduguri, Maiduguri, Nigeria \\ ${ }^{4}$ Department of Remedial Science, Mohamet Lawan College of Agriculture, Maiduguri, Nigeria \\ ${ }^{4}$ Department of Chemistry, Faculty of Science, University of Maiduguri, Maiduguri, Nigeria \\ ${ }^{5}$ Department of Planning, Research and Development, Nigerian Institute of Science Laboratory \\ Technology, Ibadan, Nigeria \\ ${ }^{6}$ Department of Forestry Technology, Mohamet Lawan College of Agriculture, Maiduguri, \\ Nigeria
}

\begin{abstract}
With consideration to food hazards and its security, this research study was conducted to determine the concentration levels of some heavy metals in vegetables cultivated in Damboa, Nigeria. Fresh samples of vegetables; Cucumber (cucumis spp) and Onion (Allium cepa) were obtained from the farms in four villages, analysed by using Atomic Absorption Spectrophotometric (AAS) techniques. Results obtained showed variations in concentration in microgram per litre ( $\mu \mathrm{g} / \mathrm{L})$. Eight heavy metals were determined; cadmium $(\mathrm{Cd})$, chromium $(\mathrm{Cr})$, copper $(\mathrm{Cu})$, iron $(\mathrm{Fe})$, manganese $(\mathrm{Mn})$, nickel $(\mathrm{Ni})$, lead $(\mathrm{Pb})$ and zinc $(\mathrm{Zn})$. The analysis revealed that; Gumsuri Ritawa village; the concentration levels in cucumber ranged from - $0.7 \pm 0.06$ to $5.7 \pm 0.06$, while in onion ranged from $0.2 \pm 0.06$ to $4.8 \pm 0.06$; highest is $\mathrm{Cd}(5.7 \mu \mathrm{g} / \mathrm{L})$ in cucumber. Gumsuri Tolori village, concentration in cucumber ranged from $-6.6 \pm 0.06$ to $0.82 \pm 0.02$, in onion is 0.27 \pm 0.01 ; highest is $\mathrm{Pb}(0.9 \mu \mathrm{g} / \mathrm{L})$ found in onion. Katchalla - Bulari village; it ranged from $-1.30 \pm$ 0.06 to $2.71 \pm 0.01$ in cucumber, and onion is $-0.90 \pm 0.1$ to $3.0 \pm 0.1$; highest is $\mathrm{Ni}(3 \mu \mathrm{g} / \mathrm{L})$ in onion, and the lowest is $\mathrm{Pb}(-1.3 \mu \mathrm{g} / \mathrm{L})$ in cucumber. Nziddamari Village; in cucumber it ranged from $-1.0 \pm 0.06$ to $2.16 \pm 0.01$ and onion ranged from $-1.0 \pm 0.06$ to $5.0 \pm 0.06$; highest is $\mathrm{Cd}$ ( 5 $\mu \mathrm{g} / \mathrm{L})$ found in onion, lowest is $\mathrm{Pb}(-1.2 \mu \mathrm{g} / \mathrm{L})$ in cucumber respectively. Values obtained falls within the recommended standard values by WHO / FAO. Conclusively, these vegetables cultivated in Damboa area was found to be wholesome and fit for consumption as at the time of this analysis.
\end{abstract}

Keywords: Concentration; Consumption; Edible Garden Plants; Food Security; Heavy Metals. 
Cite This Article: Halima Bala Mohammed, Gwana Adamu Mohammed, Kolo, Baba Gana, Hamra Abatcha Ahmed, Kolo, Mu'azu Abdullahi Kofar Na'isa, and Abubakar Aliyu. (2019). "DETERMINATIONS OF SOME HEAVY METALS IN VEGETABLES CULTIVATED IN SOME VILLAGES IN DAMBOA, NORTH - EASTERN NIGERIA." International Journal of Research - Granthaalayah, 7(11), 57-70. 10.29121/granthaalayah.v7.i11.2020.333.

\section{Introduction}

For a proper livelihood and decent life living to be obtained, food hazards, food security and the protection of our environments and their management systems must firstly to be considered in all respects. Garba and Jimoh, (2015) stated that the economic benefit derived from plants (rain fed or irrigated plant or crops) without recourse to the health implications has negative consequences on human livelihood and environmental quality. Kolo et al., (2018) Gwana et al., (2017a) and Sharma et al., (2000) stated that the protection of environment is the most vital issue today; most important human activities such as explosive population growth, rapid progress in science and technology, massive industrialisation and use of various chemicals in agriculture are the factors threatening the very quality of life. The cultivation of plants has been interesting and important sources of food and many biological substances (Bassey et al., 2016a). Food production contributes to sense of community (Bassey et al., 2019; Gwana et al., 2017b; Brown and Carter, 2003). It has educationally and skill development benefits for society, helping to nature cultural and horticultural knowledge of food production and usage. Urban and Peri - urban agriculture (UPA) is an alternative way of producing food within the cities. Food production can take place on rooftops and in backyard, community vegetable and fruit gardens and unused or public spaces (Brown and Carter, 2003). Smit and Nasr (1992) reported that, there are 200 million urban farmers in the world supplying food to 800 million people, or about $12 \%$ of the world population.

Plants are conveniently separated into those which are edible, those which serves as a source of drugs or spices, those that are of ornamental value, and so forth. Although almost intensively cultured plant rightly comes under the domain of horticulture, primary effort is centred about the various traditional "garden" plants (Gwana et al., 2017a; Akan et al., 2013; Nirmal Kumar et al., 2007; Sharma et al., 2000). The Horticulturist divides the edible garden plant into vegetables and fruits. Generally considered as vegetables are those herbaceous plants of which some portion is eaten, either cooked or raw, during the principal part of the meal, e.g. Spinach, Eggplant, Cucumber, Onion, etc. (Hornby, 2001; Estelle and Karen, 1999). Fruit, on the other hand, are plants from which a more or less succulent fruits or closely related structure is commonly eaten as a food (Hornby, 2001; Jules, 1972). The consumption of vegetables and fruits as food offer rapid and least means of providing adequate vitamins supplies, minerals and fibres. Vegetables are used as food including those used in making soups or served as integral parts of the main sources of a meal (Akan et al., 2013).

Consumption of food crops contaminated with heavy metals is a major food chain route for human exposure (Ashiq et al., 2013; Awofolu, 2005; Bonce et al., 1990). Some metals are toxic when they form poisonous soluble compounds. Certain metals have no biological role, i.e. are not essential minerals, or are toxic when in a certain form, Metal toxicity is the effect of certain metals in certain forms and doses on life (Bassey et al., 2016b; Wikipedia, 2008a; Wikipedia, 2008b; NIOSH, 1976). The distribution of heavy metals in plant body depends upon availability and 
concentration of heavy metals as well as particular plant species and its population (Alloway and Ayres, 1997; Bhata, 2002; Lees, 1994). The heavy metals or trace elements play an important role in the metabolic pathways during the growth and development of plants, when available in required concentration (Nirmal Kumar et al., 2007 Fishchbein, 1992). Many researchers have shown that some common vegetables are capable of accumulating high levels of metals from the soil (Cobb et al., 2000). Certain species of these vegetables (e.g. cabbage) are hyper-accumulators of heavy metals into the edible tissues of plants (Xiong, 1998; Watt et. al., 1994).

Out of the one hundred and twelve (112) elements in nature, about eighty (80) are metals, most of which are found only in trace amounts in the biosphere and biological materials. There are at least some twenty (20) metals or metal like elements which do give rise to well organised toxic effects in man and his ecological associates (Ashiq et al., 2013; Bunce, 1990, Watt and Cotter, 1994). These elements include; arsenic, antimony, beryllium, cobalt, chromium, lead, manganese, mercury, molybdenum, nickel and tin. These metals have been known to be toxic to man for centuries, and their carcinogenic activities have also been reviewed by (Awofolu, 2005; Okoronkwo et al., 2005; USEPA, 1986; Frust, 1977).

Among the different pollutants heavy metals have received escalating attention due to their possible injuries effects to man, animals and plants as there are recorded to be cytotoxic, mutagenic, and carcinogenic (Csuros and Csuros, 2002; Fischbein, 1992; Meittinien, 1975; BryceSmith, 1971). Heavy metals are conventionally defined as elements with metallic properties such as ductility, conductivity, stability and cat ions, legends specificity, etc. and atomic number greater than 20. The most common heavy metals contaminants are arsenic, cadmium, chromium, copper, mercury, lead, nickel, vanadium and zinc. Heavy metals form the major group of toxic pollutants among the other pollutants, as these metals temper the harmony of the ecosystem (Csuros and Csuros, 2002; Rao and Patnaik, 1999; DWAF, 1996; Huges et. al, 1980).

The objectives of this study is to determine some heavy metals in some vegetables (Cucumber and Onion) samples that were cultivated in some villages in Damboa, North - Eastern Nigeria. Despite of the enormous potential need of vegetables and fleshy fruits production and bright prospects in Nigeria, there are various factors and challenges facing the production such produce. Factors such as human activities, lack of base line data of the soils and Sanitised cultivation, Poor growth and harvesting techniques, pest's protection management procedures, etc., may lead to the contamination of the vegetables and fruits with the heavy metals. Hence, the necessity to carry out this study becomes necessary, will be useful in revealing the heavy metal concentration in vegetables and fruits consumed by human and animals in Damboa, Nigeria and data obtained will serve as base line information for further use.

\section{Materials and Methods}

\subsection{Study Area}

This study was carried out in four villages, namely; Gumsuri - Ritawa village, Gumsuri - Tolori village, Katchalla - Bulari village and Nziddamari village, in Damboa Local Government of Borno State, Nigeria. It has headquarters in the town of Damboa. It has an area of 6,219 $\mathrm{km} 2$ and a population of 23,300 at the 2006 Census. It has an area density of $3.75 \mathrm{~km} 2$ per person. The postal 
code of the area is 601, with a bearing or coordinate of Longitude $110091011 \mathrm{~N}$ and 120451011 $\mathrm{E}$ and Latitude $11.15000 \mathrm{~N}$ and $12.75000 \mathrm{0E}$. It is one of the sixteen local government areas that constitute the Borno Emirate, a traditional state located in Borno state, Nigeria (Kolo et al., 2018; Gwana, et al., 2013).

\subsection{Materials}

All of the materials and reagents used for this analysis were of analytical grade from Laboratory Unit, AHP Department, Mohamet Lawan College of Agriculture, Maiduguri and National Agency for Food and Drug Administration and Control (NAFDAC), Maiduguri, Nigeria.

\subsection{Methods}

In the course of carrying out this research work, all the environment and materials used are kept hygienically clean and Standard Operation Procedures (SOP) were observed strictly.

\subsubsection{Sample and Sampling}

At early hours (06:30 am) in the morning, 2 fresh samples vegetables were obtained directly from the garden farms from four locations, i.e. in Gumsuri - Ritawa village, Gumsuri - Tolori village, Katchalla - Bulari village and Nziddamari village of Damboa Local Government of Borno State, Nigeria. These samples are; the fruit vegetable, local Cucumber (cucumis spp). and the root or bulb vegetable Onion (Allium cepa). These were packed in polythene bag each, labelled and transported to the Laboratory as described by methods applied by Ashiq et al., (2013).

\subsubsection{Sample Preparation}

In the laboratory, the samples were unpacked and washed successively under tap water gently, acidified water, distilled water and doubled or repeated with distilled water gently. Moisture and water droplets were removed with aid of blotting papers. These samples were then reduced to pieces by cutting with plastic knife, dried, first at room temperature for several days and then in hot air oven at $60 \pm 5$ OC for 48 hours, as described by Ashiq et al., (2013). Fresh and dried weights of the samples were determined, as described by Akan et al., (2013).

\subsubsection{Ashing the Samples}

Air dried plant materials (vegetables) were pulverized into powder, transferred into crucible dish and put to muffle furnace, heated at 500 oC for 3 hours. It was then removed and allowed in a desiccator to cooled and dried, as described by Ashiq et al., (2013).

\subsubsection{Digestion of The Samples}

To a beaker $0.5 \mathrm{~g}$ of the ashed samples was transferred in to $250 \mathrm{ml}$ beaker each. $10 \mathrm{ml}$ of $6 \mathrm{M}$ Hydrochloric acid were also added to each and covered the beaker with watch glass and heat for 15 minutes, removed and cooled. $1 \mathrm{ml}$ of concentrated Nitric acid was added and heated to evaporated to direness and dehydrated the Sillica. $1 \mathrm{ml}$ of $6 \mathrm{M}$ of Hydrochloric acid was added 
again. $10 \mathrm{ml}$ of distilled water was added and heated to redissolved, cooled filtered with Filter paper Whatman No. 541 in to $100 \mathrm{ml}$ volumetric flask up to the mark levelled. It was the transferred into polythene bottle for elements analysis, as described by AOAC, (1990).

\subsubsection{Sample Analysis}

The method applied in the evaluations of some mineral composition of each plant materials samples after the Ashing and the digestion, was by Atomic Absorption Spectrophotometric (AAS) techniques as described by AOAC, (1990).

\subsection{Data Analysis}

Data obtained from this research study were subjected to statistical tools of analysis using mean for the measurement of central tendency, the percentage and standard deviations for measurement of dispersion and or discrepancy within the variables being obtained and its' significance, as described by Stroud and Booth, (2001).

\section{Results}

The results of the analysis on the determinations of heavy metals in vegetables (Cucumber and Onion) that were cultivated in four villages in Damboa Local Government, Borno state of Nigeria were obtained in microgram per litre $(\mu \mathrm{g} / \mathrm{L})$ and presented in percentage, are presented in the tables as follows: -

Table 1 present the mean concentration levels of some heavy metals determined in some types of vegetables obtained from Gumsuri - Ritawa village. The concentration levels in cucumber ranged from $-0.7 \pm 0.06$ to $5.7 \pm 0.06$, while in onion ranged from $0.2 \pm 0.06$ to $4.8 \pm 0.06$. The highest in concentration levels is in Clcucumber with $\mathrm{Cd}(5.7 \mu \mathrm{g} / \mathrm{L})$, and lowest concentration is in cucumber having $\mathrm{Pb}(-0.7 \pm 0.06 \mu \mathrm{g} / \mathrm{L})$.

Table 1: Mean concentration of some heavy metals determined in vegetables obtained from Gumsuri - Ritawa village, Damboa.

\begin{tabular}{|c|c|c|c|c|c|c|c|c|}
\hline $\begin{array}{c}\text { Type of } \\
\text { samples }\end{array}$ & \multicolumn{7}{|c|}{ Mean concentration in microgram per litre $(\boldsymbol{\mu g} / \mathbf{L})$} \\
\cline { 2 - 9 } & $\mathbf{C d}$. & $\mathbf{C r}$ & $\mathbf{C u}$. & $\mathbf{F e}$. & $\mathbf{M n .}$ & $\mathbf{N i}$. & $\mathbf{P b}$. & $\mathbf{Z n .}$ \\
\hline Cucumber & $5.7 \pm 0.06$ & $0.13 \pm 0.02$ & $0.07 \pm 0.02$ & $1.58 \pm 0.01$ & $0.41 \pm 0.01$ & $0.40 \pm 0.01$ & - & $0.18 \pm 0.01$ \\
& & & & & & & $0.7 \pm 0.06$ & \\
\hline Onion & $4.8 \pm 0.06$ & $0.09 \pm 0.04$ & $2.24 \pm 0.01$ & $1.58 \pm 0.01$ & $0.53 \pm 0.01$ & $0.56 \pm 0.01$ & $0.2 \pm 0.06$ & $0.71 \pm 0.01$ \\
\hline *Standard & 0.01 & 1.30 & 10.0 & 1.30 & 3.0 & - & 2.50 & 5.0 \\
\hline
\end{tabular}

*SOURCE: WHO / AOAC, revision 2, section 973 - 42B(b).

Table 2 present the mean concentration levels of some heavy metals determined in two types; the fruit vegetable, local cucumber (cucumis spp) the root or bulb vegetable onion (Allium cepa) obtained from Gumsuri - Toluri village. The concentration level of heavy metals determined in cucumber ranged from $-6.6 \pm 0.06$ to $0.82 \pm 0.02$, while in onion is $0.27 \pm 0.01$; highest is $\mathrm{Pb}(0.9$ $\mu \mathrm{g} / \mathrm{L})$ found in Onion and the lowest concentration is also Lead $(\mathrm{Pb})$ in the Cucumber $(-0.6 \mu \mathrm{g}$ / L). 
Table 2: Mean concentration of some heavy metals determined in vegetables obtained from

Gumsuri - Toluri village, Damboa.

\begin{tabular}{|c|c|c|c|c|c|c|c|c|}
\hline \multirow{2}{*}{$\begin{array}{l}\text { Type of } \\
\text { samples }\end{array}$} & \multicolumn{8}{|c|}{ Mean concentration in microgram per litre $(\mu \mathrm{g} / \mathrm{L})$} \\
\hline & Cd. & $\mathbf{C r}$ & $\mathrm{Cu}$. & Fe. & Mn. & Ni. & Pb. & Zn. \\
\hline Cucumber & $0.62 \pm 0.01$ & $0.18 \pm 0.01$ & $0.40 \pm 0.01$ & $0.82 \pm 0.02$ & $0.32 \pm 0.01$ & $0.40 \pm 0.01$ & $\begin{array}{c}- \\
6.6 \pm 0.06\end{array}$ & $0.37 \pm 0.01$ \\
\hline Onion & $0.88 \pm 0.02$ & $0.32 \pm 0.01$ & $0.58 \pm 0.01$ & $0.45 \pm 0.01$ & $0.40 \pm 0.01$ & $0.56 \pm 0.01$ & $0.9 \pm 0.01$ & $0.27 \pm 0.01$ \\
\hline *Standard & 0.01 & 1.30 & 10.0 & 1.30 & 3.0 & - & 2.50 & 5.0 \\
\hline
\end{tabular}

*SOURCE: WHO / AOAC, revision 2, section 973 - 42B(b).

Table 3 present the mean concentration levels of some heavy metals determined in some vegetables obtained from Katchalla - Bulari village. From the results, it ranged from - $1.30 \pm 0.06$ to $2.71 \pm$ 0.01 in cucumber, and onion is $-0.90 \pm 0.1$ to $3.0 \pm 0.1$; the highest is $\mathrm{Ni}(3 \mu \mathrm{g} / \mathrm{L})$ in onion. The highest concentration level is Nickel (Ni) in onion with $3.00 \mu \mathrm{g} / \mathrm{L}$ and lowest in concentration level is Lead $(\mathrm{Pb})$ in cucumber with $-1.3 \mu \mathrm{g} / \mathrm{L}$ respectively.

Table 3: Mean concentration of some heavy metals determined in vegetables obtained from Katchalla - Bulari village, Damboa.

\begin{tabular}{|c|c|c|c|c|c|c|c|c|}
\hline $\begin{array}{c}\text { Type of } \\
\text { samples }\end{array}$ & \multicolumn{7}{|c|}{ Mean concentration in microgram per litre $(\boldsymbol{\mu g} / \mathbf{L})$} \\
\hline & $\mathbf{C d}$. & $\mathbf{C r}$ & $\mathbf{C u}$. & $\mathbf{F e}$. & $\mathbf{M n .}$ & $\mathbf{N i}$ & $\mathbf{P b}$. & $\mathbf{Z n .}$ \\
\hline Cucumber & $0.83 \pm 0.01$ & $0.18 \pm 0.01$ & $2.71 \pm 0.01$ & $0.21 \pm 0.01$ & $0.12 \pm 0.01$ & $0.42 \pm 0.01$ & - & $0.62 \pm 0.01$ \\
& & & & & & & $1.30 \pm 0.06$ & \\
\hline Onion & $1.04 \pm 0.01$ & $0.17 \pm 0.01$ & $1.69 \pm 0.01$ & $0.48 \pm 0.01$ & $0.40 \pm 0.01$ & $3.00 \pm 0.1$ & - & $0.98 \pm 0.01$ \\
& & & & & & & $0.90 \pm 0.1$ & \\
\hline *Standard & 0.01 & 1.30 & 10.0 & 1.30 & 3.0 & - & 2.50 & 5.0 \\
\hline
\end{tabular}

*SOURCE: WHO / AOAC, revision 2, section 973 - 42B(b).

Table 4. present the mean concentration levels of some heavy metals determined in some types of vegetables obtained from Nziddamari village. The concentration levels of the heavy metals determined in cucumber ranged from $-1.0 \pm 0.06$ to $2.16 \pm 0.01$ and onion ranged from $-1.0 \pm$ 0.06 to $5.0 \pm 0.06$; highest is $\mathrm{Cd}$ with $5 \mu \mathrm{g} / \mathrm{L}$ found in onion with while lowest is $\mathrm{Pb}$ had $-1.2 \mu \mathrm{g}$ / $\mathrm{L}$ in cucumber respectively.

Table 4: Mean concentration of some heavy metals determined in vegetables obtained from Nziddamari village, Damboa.

\begin{tabular}{|c|c|c|c|c|c|c|c|c|}
\hline \multirow{2}{*}{$\begin{array}{c}\text { Type of } \\
\text { samples }\end{array}$} & \multicolumn{7}{|c|}{ Mean concentration in microgram per litre $(\boldsymbol{\mu g} / \mathbf{L})$} \\
\cline { 2 - 9 } & $\mathbf{C d .}$ & $\mathbf{C r}$ & $\mathbf{C u .}$ & $\mathbf{F e}$ & $\mathbf{M n .}$ & $\mathbf{N i .}$ & $\mathbf{P b}$. & $\mathbf{Z n}$. \\
\hline Cucumber & $0.83 \pm 0.01$ & $0.16 \pm 0.01$ & $2.16 \pm 0.01$ & - & $0.12 \pm 0.01$ & $0.5 \pm 0$ & - & $0.75 \pm 0.01$ \\
& & & & $1.20 \pm 0.06$ & & & $1.20 \pm 0.06$ & \\
\hline Onion & $5.0 \pm 0.06$ & $0.12 \pm 0.01$ & $2.60 \pm 0.06$ & - & $0.21 \pm 0.01$ & $0.4 \pm 0.06$ & - & $1.06 \pm 0.01$ \\
& & & & $1.00 \pm 0.06$ & & & $1.00 \pm 0.06$ & \\
\hline$*$ Standard & 0.01 & 1.30 & 10.0 & 1.30 & 3.0 & - & 2.50 & 5.0 \\
\hline
\end{tabular}

*SOURCE: WHO / AOAC, revision 2, section 973 - 42B(b).

Table 5 present the percentage concentration levels of some heavy metals determined in some types of vegetables obtained from Gumsuri - Ritawa, Damboa. From the results, the concentration 
level in cucumber ranges from -9.0 to $73.4 \%$ in onion is 44.8 to $0.8 \%$ amongst the heavy metal analysed respectively.

Table 5: Percentage concentration of some heavy metals determined in vegetables obtained from Gumsuri - Ritawa, Damboa.

\begin{tabular}{|l|l|l|l|l|l|l|l|l|}
\hline \multirow{2}{*}{$\begin{array}{l}\text { Type of } \\
\text { samples }\end{array}$} & \multicolumn{6}{|c|}{ Mean concentration in percentage (\%) } \\
\cline { 2 - 9 } & Cd. & Cr & Cu. & Fe. & Mn. & Ni. & Pb. & Zn. \\
\hline Cucumber & 73.4 & 1.7 & 0.9 & 20.3 & 5.3 & 5.1 & -9.0 & 2.3 \\
\hline Onion & 44.8 & 0.8 & 20.9 & 14.6 & 4.9 & 5.2 & 1.9 & 6.6 \\
\hline
\end{tabular}

Table 6 present the percentage concentration levels of some heavy metals determined in some types of vegetables obtained from Gumsuri - Tolori ward of Damboa area. The concentration level in percentage of heavy metals determined in cucumber is -89.1 to $-5.2 \%$, while in onion is 6.3 to $20.5 \%$.

Table 6: Percentage concentration of some heavy metals determined in vegetables obtained from Gumsuri - Tolori, Damboa.

\begin{tabular}{|l|l|l|l|l|l|l|l|l|}
\hline \multirow{2}{*}{$\begin{array}{l}\text { Type of } \\
\text { samples }\end{array}$} & \multicolumn{6}{|c|}{ Mean concentration in percentage (\%) } \\
\cline { 2 - 9 } & $\mathbf{C d}$. & $\mathbf{C r}$ & $\mathbf{C u}$. & Fe. & Mn. & Ni. & Pb. & Zn. \\
\hline Cucumber & -17.8 & -5.2 & 0.9 & 20.3 & 5.3 & 5.1 & -9.0 & 2.3 \\
\hline Onion & 20.5 & 7.4 & 20.9 & 14.6 & 4.9 & 5.2 & 1.9 & 6.6 \\
\hline
\end{tabular}

Table 7 present the percentage concentration levels of some heavy metals determined in four types of vegetables and fruits obtained from Katchalla - Bulari. The highest concentration level is $\mathrm{Cu}$ in cucumber with -38.5 to $71.5 \%$ and the lowest concentration is also $\mathrm{Pb}$ in the cucumber with $38.5 \%$ only.

Table 7: Percentage concentration levels of some heavy metals determined in vegetables obtained from Katchalla Bulari, Damboa.

\begin{tabular}{|l|l|l|l|l|l|l|l|l|}
\hline \multirow{2}{*}{$\begin{array}{l}\text { Type of } \\
\text { samples }\end{array}$} & \multicolumn{6}{|c|}{ Mean concentration in percentage (\%) } \\
\cline { 2 - 9 } & Cd. & Cr & Cu. & Fe. & Mn. & Ni. & Pb. & Zn. \\
\hline Cucumber & 21.9 & 4.7 & 71.5 & 5.5 & 3.2 & 11.1 & -34.3 & 16.4 \\
\hline Onion & 15.2 & 2.5 & 24.6 & 7.0 & 5.8 & 43.7 & -13.1 & 14.3 \\
\hline
\end{tabular}

Table 8 present the percentage concentration levels of some heavy metals determined in four types of vegetables and fruits obtained from Nziddamari in Damboa. From the results, the highest concentration level is $\mathrm{Cd}$ in onions $(67.7 \%)$ and the lowest concentration is also $\mathrm{Pb}$ in the cucumber $(-56.6 \%)$ respectively.

Table 8: Percentage concentration levels of some heavy metals determined in vegetables obtained from Nziddamari, Damboa.

\begin{tabular}{|l|l|l|l|l|l|l|l|l|}
\hline \multirow{2}{*}{$\begin{array}{l}\text { Type of } \\
\text { samples }\end{array}$} & \multicolumn{6}{|c|}{ Mean concentration in percentage (\%) } \\
\cline { 2 - 10 } & Cd. & Cr & Cu. & Fe. & Mn. & Ni. & Pb. & Zn. \\
\hline Cucumber & 59.6 & 7.5 & 10.9 & -50.6 & 5.7 & 23.6 & -56.6 & 35.4 \\
\hline Onion & 67.7 & 1.6 & 38.2 & -13.3 & 2.8 & 5.4 & 13.5 & 14.3 \\
\hline
\end{tabular}




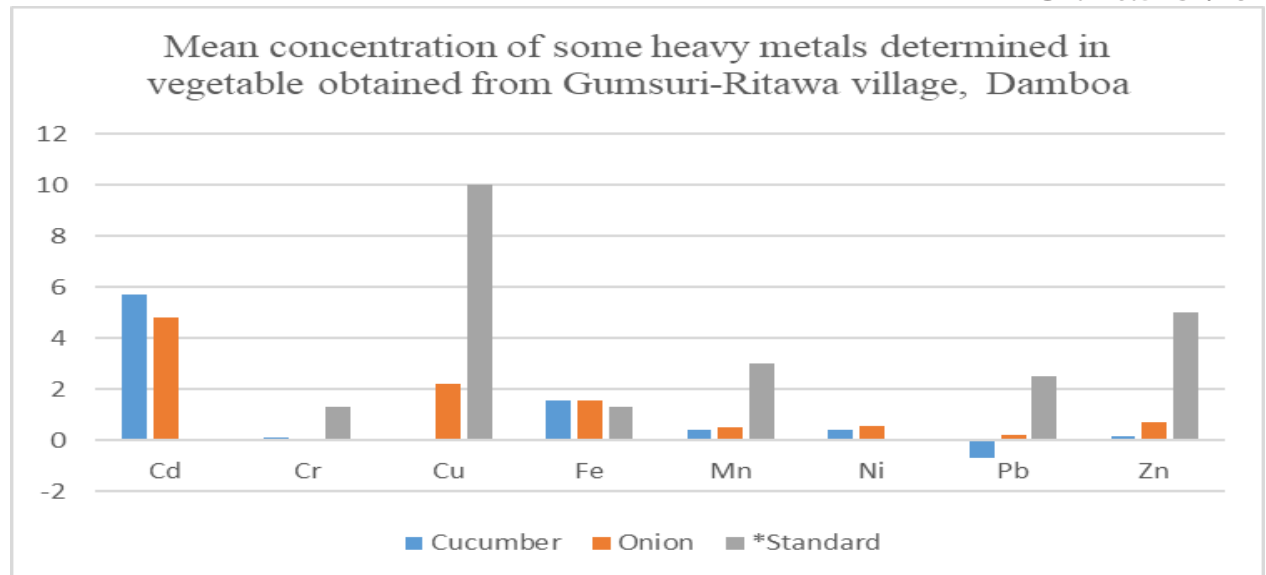

Figure I: Showed the mean concentration of some heavy metals determined in vegetables obtained from Gumsuri -Rituwa village, Dambua.

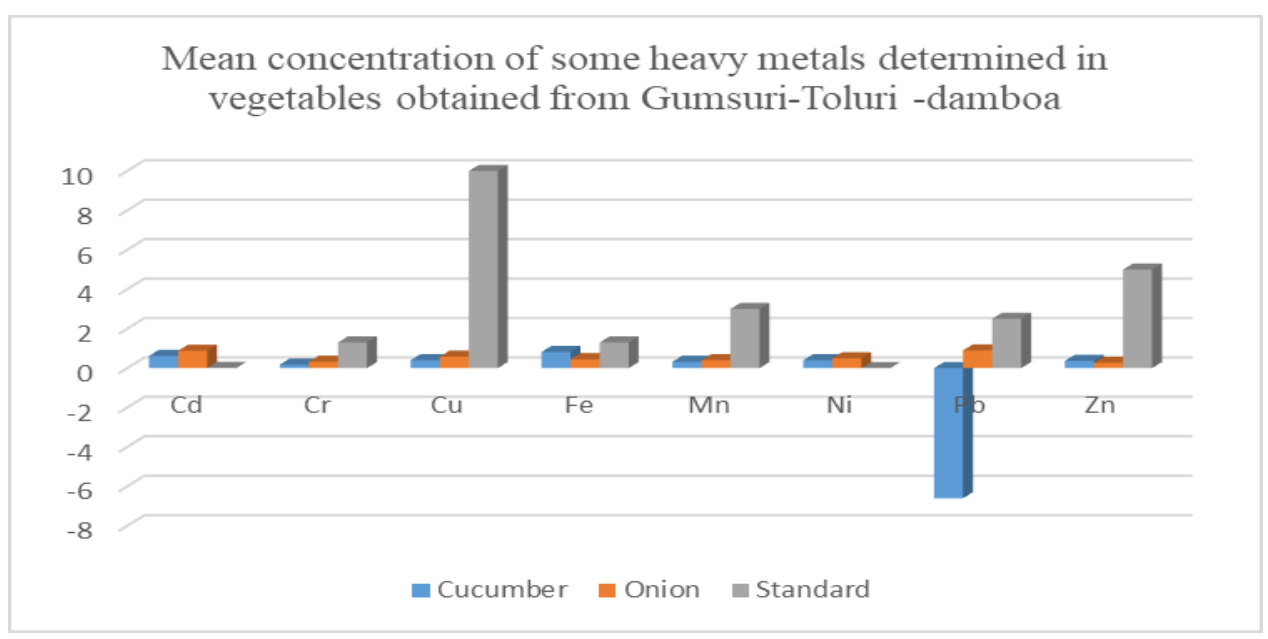

Figure II: Showed the mean concentration of some heavy metals determined in vegetables obtained from Gumsuri-Toluri, village, Dambua.

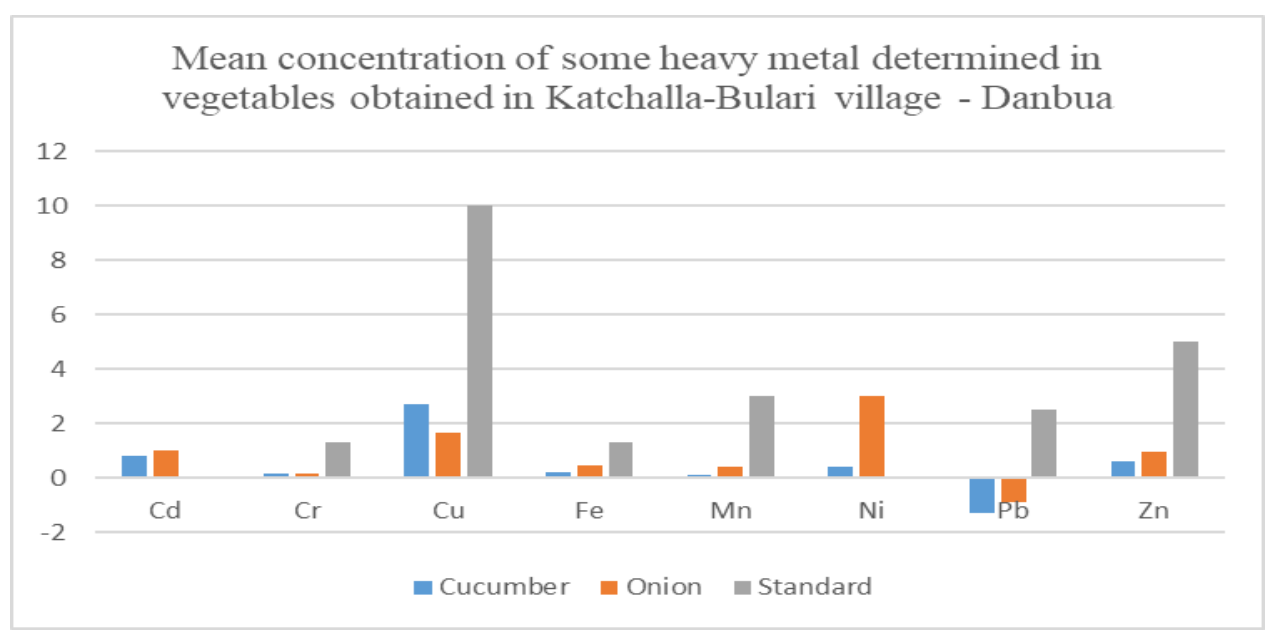

Figure III: Showed the mean concentration of some heavy metals determined in vegetables obtained from Katchalla-Bulari, village, Dambua. 


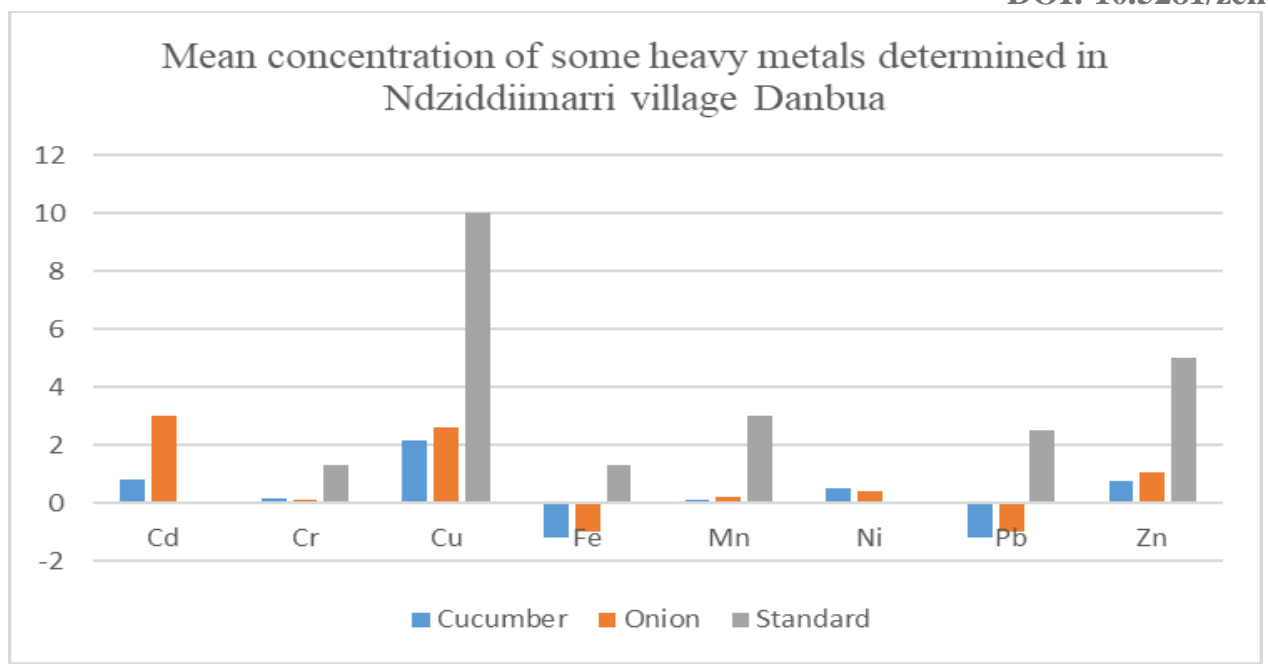

Figure IV: Showed the mean concentration of some heavy metals determined in vegetables obtained from Nziddamarii, village, Dambua.

\section{Discussion}

Plants are separated into that edible and non-edible have many uses. The edible ones serve and use as a source of foods, drugs or spices, others are for ornamental value and others purposes. Cultured plants are mostly under the domain of horticulture and this is centred about the various garden plants traditionally. Vegetable plants are used as food including those used in making soups or eaten fresh and raw or served as parts of the main sources of a meal and the consumption these vegetable plants providing adequate vitamins supplies, minerals, phytochemicals, plant proteins, fats and oils, etc. Plant food and its products, not only to be considered to its usefulness, nutritional and medicinal values, but its hazard and security to have be considered for the wellbeing human and animals also.

Thus, in this research study, heavy metals or trace elements are not left behind when considering the important role play in the metabolic pathways during the growth and development of plants and animals, when available in required concentration levels. Heavy metals are non-biodegradable and have persistent environmental contaminants which may be deposited on the surfaces and then absorbed into the tissues of the vegetables plants, by absorbing them from deposits on the parts of the plants exposed to the air from polluted environment as well as from contaminated soils. Heavy metals contamination in vegetables cannot be underestimated as these food stuffs are important components of human and animal diets. With consideration to Kolo et al., (2018) who stated that, heavy metal contamination of food items is one of the most important aspects of food quality assurance. The International and national regulations on food quality have lowered the maximum permissible levels of toxic metals in food items. In this research study, vegetables sampled were obtained from four different farms; in four villages (Gumsuri - Ritawa, Gumsuri - Tolori, Katchalla - Bulari and Nziddamari), in Damboa, North - Eastern of Nigeria. These samples were analysed and the concentration level of the heavy metals values were determined (cadmium, chromium, copper, iron, Manganese, nickel, lead and zinc). This research study supports the works of most authors, especially Kolo et al., (2018), Akan et al., (2013) and Ashiq et al., (2013). 
The vegetable samples that were cultivated and obtained from Gumsuri - Ritawa village, Damboa, were determined that, Onion contained heavy metals at a concentration level of 4.8 to $0.2 \mu \mathrm{g} / \mathrm{L}$, i.e. $44.8 \%$ to $1.9 \%$. The results revealed that, it had higher amount of cadmium, followed by copper, iron, zinc, nickel and manganese. It had lead at concentration level of $1.9 \%$ with less chromium of $0.9 \%$. Cucumber was found to contain heavy metals at concentration levels of 5.7 $\mu \mathrm{g} / \mathrm{L}(73.4 \%)$ to $-0.9 \mu \mathrm{g} / \mathrm{L}(-9 \%)$. That means, it contained high amount cadmium also, followed by iron, manganese and nickel. It had fewer amounts of zinc, chromium and copper with a negative value of lead. There was lesser amount of nickel, manganese, zinc and chromium with a negative value of lead. Copper had not been found in the analysis.

In another observation, the two vegetables (Cucumber and Onion) obtained from Gumsuri - Ritawa village, all contained higher amount of iron concentration level, they contained higher amount of cadmium. Only onion had high amount of copper and lesser amount of lead. All of the vegetables obtained from the village contained lesser amount chromium, manganese, nickel and zinc. The results obtained from this study are lower than the recommended standard value by WHO / FAO, which makes the vegetables obtained from this village safe for consumption. It is very rich minerals content.

These results of the analysed two (2) vegetables, obtained from Gumsuri - Tolori village, it revealed that in onion, there are enough lead, copper, nickel and iron, moderate manganese and chromium, and least of zinc concentration levels. In cucumber there are much concentration levels of iron and cadmium, moderate amount of copper, nickel, zinc, manganese, and chromium, with least amount of lead. That is, the two vegetables (Cucumber and Onion) from this area had higher concentration levels of the heavy metals (cadmium, copper and nickel). Cucumber had higher concentration level of iron. More amount the heavy metals; chromium and manganese in the two vegetables was revealed from this analysis. The vegetables (Cucumber and Onion) contained more amounts of zinc concentration levels. Only Onion had higher level of lead, but cucumber contained negative value of concentration levels of heavy metal.

The two vegetable samples that were cultivated and obtained from Katchalla - Bulari village, Damboa, were determined that in onion, it was found to contained heavy metals at a concentration level of 3.0 to $-0.9 \mu \mathrm{g} / \mathrm{L}$, i.e. $43.7 \%$ to $-13.1 \%$. The results revealed that, it had higher amount of nickel, followed by copper, cadmium and zinc. It also contained iron, manganese chromium at moderate concentration levels. Lead was found at a negative concentration level. Cucumber sampled obtained in this village, contained moderate amount of heavy metals at concentration levels of $2.7 \mu \mathrm{g} / \mathrm{L}(71.5 \%)$ to $-1.3 \mu \mathrm{g} / \mathrm{L}(-34.3 \%)$. The analysis revealed that it contained higher amount of copper, moderate amount of cadmium and zinc at concentration levels. It had lesser amount of nickel, iron, chromium and manganese concentrations, with a negative level of lead.

It was observed that in this research study, the vegetables cultivated in this area (Katchalla - Bulari village); both the 2 vegetables (Cucumber and Onion) had more concentration levels of cadmium and chromium, with negative value of lead. Both Cucumber and Onion contained moderate amounts of copper. Onion had more iron concentration levels in them. Only Onion had higher amount of nickel level and Cucumber had lesser concentration levels of the nickel. cucumber and onion had moderate amounts of zinc concentration levels. 
Out of the two samples obtained from Nziddamari village, the results of the analysis revealed that, onion sampled had higher amount of the heavy metals determined at a mean concentration levels of $5.0 \mu \mathrm{g} / \mathrm{L}(67.7 \%)$ to $-1.0 \mu \mathrm{g} / \mathrm{L}(-13.5 \%)$ respectively. The results also revealed that, it had higher amount of cadmium, followed by copper and zinc. It had moderate amount of nickel, manganese and chromium. And negative value of concentration levels of iron and lead at $-1.0 \mu \mathrm{g}$ / L. Cucumber sampled obtained in this area, contained moderate amount of heavy metals at concentration levels of $2.2 \mu \mathrm{g} / \mathrm{L}(62 \%)$ to $-1.2 \mu \mathrm{g} / \mathrm{L}(-56.6 \%)$. The analysis revealed that it contained higher amount of copper concentration, more amount of cadmium, zinc and nickel. Lower concentration levels of chromium and manganese, and negative concentration levels iron and lead. In lettuce, it revealed that, the mean concentration levels of the metals ranges from 0.1 $\mu \mathrm{g} / \mathrm{L}(1.1 \%)$ to $2.1 \mu \mathrm{g} / \mathrm{L}(29.5 \%)$. It contained iron and lead at higher concentration, copper and zinc at more concentration levels. It had manganese and cadmium at lower levels of concentration, and, nickel and chromium at least concentration levels only.

From these two (2) vegetables that were obtained from Nziddamari village, it was observed that, onion had high concentration of cadmium and zinc. Cucumber and onion and had more amount of copper. Cucumber had adequate concentration of zinc. All of the vegetables determined from this area had lesser concentration of chromium, manganese and nickel. Onion and cucumber had negative values of lead concentration levels. When compared, it was found that the heavy metals values in vegetables determined were less than the standard recommended values These makes vegetables in this area were rich both macro and micro elemental nutrients and wholesome, fit for consumption.

All the two vegetables sampled, cultivated in these areas were analysed and found that, they are rich in minerals nutrients, both macro and micro elements which are used by both plants animal metabolism. That means, the vegetables that are cultivated in these areas are good and healthy for consumption by human beings and herbivores animals. This is because they did not exceed the standard recommended values for consumption, i.e. they were found wholesome conclusively.

\section{Conclusion}

Heavy metals contamination in vegetables cannot be underestimated as these food stuffs are important components of human diet, and its contamination of food items is one of the most important aspects of food hazards food security, i.e., food quality assurance. Persistent environmental contamination with heavy metals (which are non-degradable) may be deposited on the surfaces and then absorbed into the tissues of the vegetables plants, by absorbing them from deposits on the parts of the plants exposed to the air from polluted environment as well as from contaminated soils.

In this research study, two different type of vegetables sampled were obtained from four different farms; in four villages (Gumsuri - Ritawa, Gumsuri - Tolori, Katchalla - Bulari and Nziddamari), in Damboa, North - Eastern Nigeria. The results of the analyses obtained from the four (4) villages, it revealed that, enough amount of the eight of the heavy metals being determined (comprises of macro micro elements), are present in the two vegetables that were analysed from these areas had higher concentration levels of the heavy metals determined; cadmium, chromium, copper, Iron, manganese, nickel, lead and zinc. 
It was observed that, the two vegetables (Cucumber and Onion) obtained from the said villages, all contained higher amount of iron concentration level and higher amount of cadmium. Only onion had high amount of copper and lesser amount of lead. All of the vegetables obtained from the village contained lesser amount chromium, manganese, nickel and zinc and it is less than the standard recommended values given by WHO and FAO. These make the vegetables obtained from these villages safe for consumption. It is very rich in minerals content, i.e. found that, they are rich in minerals nutrients, both macro and micro - elements which are used by both plants and animal metabolism. That means, they are good and healthy for consumption by human beings, this is because they did not exceed the standard recommended values for consumption, that is, they were found wholesome.

\section{Recommendations}

We recommend that restudies need to be carried out on heavy metals in vegetables and fruits in the study areas, in order to ascertain and determine the other heavy metals that are not involved in this study and the uses of these vegetables (Cucumber and Onion) from this area are found fit and wholesome for consumption.

\section{Acknowledgement}

It is a great pleasure to acknowledge the great role played by, especially, Chemistry Laboratory, Department of Chemistry, University of Maiduguri, Maiduguri; Laboratory Unit, A. H. P. T. Department, Mohamet Lawan College of Agriculture, Maiduguri, and NAFDAC, Maiduguri, Nigeria for their support and an assistance given to us. We owe particular thanks to all those researchers cited in this piece of work and most grateful to all persons who have helped or assisted in one way or the other in the course of conducting this research study. Thanking you and very grateful to you all.

\section{References}

[1] Akan, J.C; Kolo, B.G; Yikala, B.S and Ogugbuaja V.O. Determination of Some Heavy Metal in Vegetable Samples from Biu Local Government Area, Borno State, North-Eastern Nigeria: International Journal of Environmental Monitoring and Analysis. 1 (2), 2013, pp. 40 - 46. 10.11648/j.ijema.2013102.11.

[2] Alloway, B. J and Ayres D. C. Chemistry Principal for Environment Pollution, Blackie Academic and Professional, 1st Ed, 1997, pp. 190 - 221.

[3] AOAC, Official Methods of Analysis. Association of Official Analytical Chemists, AOAC Press, Gaithersburg, USA, 15th Edition; 1990, Pp:

[4] Ashiq, H. L., Eugenia, P. L., Sasya, T., Ganie, S. A., Mohammed S. W., Ani K., Sajad H. W. and Fayaz A. W. Accumulation of Heavy Metals on Soil and Vegetable Crops Grown on Sewage and Tube Well Water Irrigation, Academic Journals, 8 (44), 2013, pp. 2187 - 2193. http://www.academicjournals.org.SRE.

[5] Awofolu, O. D. R. A Survey of Trace Metals in Vegetables, Soil and Lower Animal along some selected Major Roads in Metropolitan, Lagos. Environmental Monitoring and Assessment, 105, 2005, $431-447$.

[6] Bassey, E. E., Gwana, A. M., Halima, B. M., Muhammed, A. B., Buhari, B. Y., Umeh, S. O., Abubakar, M. and Mbanusi, B. Comparative Phytochemical Screening and invitro Antimicrobial 
Activity of Aqueous, Ethanolic and Ethyl Acetate Extracts of Stem Bark and Leaves of Horse Radish (Moringa oleifera) Plant, 2 (9), 2016, pp: 61 - 76.

[7] Bassey, E. E., Gwana, A. M., Mu'azu, A. K and Modu, G. U. Quantitative Phytochemicals Screening and Antimicrobial Susceptibility Patterns of Coconut Oil Extract on Some Selected Bacteria and Fungi, World Journal of Advance Research and Review, 1 (3), 2019, pp: 1 - 13.

[8] Bhata, S. C. Environmental Chemistry, CBS Publishers and Distribution, New Delhi, 2002, pp. 442.

[9] Brown, K.H. and Carter, A. Urban Agriculture and Community Food Security in the United State or America, in: Farming from the City Centre to the Urban Fringe, Community Food Security Coalition, Venice, California, 2003.

[10] Bryce-Smith, D. Lead Pollution; A Growing Hazard to Public Health Chemistry in Britain. 7 (2), 1971, pp. $54-56$.

[11] Bunce, N. J. Environmental Chemistry, Winners Publishing Ltd, Winnipeg, Canada, 1990, pp. 206 $-247$.

[12] Cobb, G. P., Sands, K., Waters, M., Wixson, B. G. and Dorward-King, E. Life. Accumulation of Metals by Garden Vegetables, Journal of Environmental Quality, (29), 2000, pp. 934 - 939.

[13] Csuros, M. and Csuros, C. Environmental Sampling and Analysis for Metals, Lewis Publisher, CRC Press, New York, 2002, pp. 237 - 238.

[14] DWAF Department of Water Affairs and Forestry. South Africa Water Quality Guidelines Domestics Uses, (2nd ed). Pretoria; Department of Water Affair and Forestry, Pretoria, 1996.

[15] Estelle Levetin and Karen McMahon. Plant Life Cycle, Fruits and Seeds, In: Plants and Society, WCB/McGraw-Hill Company, Incorporation, U.A.S, 2nd edition, 1999, pp. 85 - 92. www.mhhe.com

[16] Fishchbein, A. Occupation and Environmental Lead Exposure in Environment and Occupation Medicine, Ron, WW (ed), Little Brown, 1992.

[17] Garba, I. and Jimoh, W. L. O. Evaluation of Heavy Metals and Macro - Elements in Irrigated Vegetables from Challawa - Yandoya and Kano River Basin Project, in Nigeria, International Journal of Scientific Research and Engineering Studies, 2 (2), 2015, pp: 18 - 32.

[18] Gwana, A. M., Bassey, E. E., Buhari, B. Y., Malah, A. M., Umaru, B. W., Mohammed, L. S., Shettima, U. K. and Halima, M. B. 2017a Role of Slt: Environmental Impact Assessments and Statements Concept, International Journal of Environmental Protection and Policy, 5 (6-1), 2017a, pp: $1-7$.

[19] Gwana, A. M., Bassey, E. E., Hauwa, L. B., Halima, M. B., Mustapha, U. M., Ali, M. and Laku, D. Appraisal of Some Heavy Metals and Elements in Irrigated Vegetables and Fruit Cultivated in College Farm, Maiduguri, International Journal of Applied Agricultural Science, 3 (3), 2017b, pp: $78-86$.

[20] Gwana, A. M., Echeonwu, G. O. N., Auwal, M. S., Bagudu, B. Y., Sa'adatu, H. S., Fatima, A. L, and Abdullah, S..Study Area and Location; In: Survey on Hepatitis B Surface Antigen (Hbs Ag) Amomgst the Community of Mohamet Lawan College of Agriculture, Maiduguri, Borno State, North - Eastern Nigeria. Journal of Laboratory Science, 2 (1), 2013, pp. 1 - 6.

[21] Hornby, A.S. Oxford Advanced Learner's Dictionary, Oxford University Press, Great Clarendon Street, Oxford OX2 6DP, New York, 6th edition, 2001, pp. 479 - 1325.

[22] Huges, M.K; Lepp, W.W and Philips, D.A. Arial Heavy Metal Pollution and Termestial Ecosystem, Advance Ecological Research, 11, 1980, pp. 217 - 227.

[23] Jules Janick. Horticultural Science, H.W. Freeman and Company, U.S.A, 2nd edition, 1972, pp. 32 -39 .

[24] Kolo, B. G, Halima, M. B., Gwana, A. M., Mu'azu, K. N. and Modu, G. U. 2018 Appraisal of Some Heavy Metals in Some Selected leafy - Vegetables Cultivated in Damboa, North - Eastern of Nigeria, International Journal of Multidisciplinary Research and Study, 1 (3), 2018, pp: 266 284. 
[25] Less, J.A. Modelling the Magnetic Properties of Natural and Environmental Materials, Phothesis, Coventry University., 1994. pp. 36 - 97.

[26] Meittinien, J.K. The Accumulation and Excretion of Heavy Metalals in Aquatic Environment, Peter A. (ed) Krenkal Perganon Press, 1975, pp. 155.

[27] National Institution Occup. Safety and Health. "Criteria for Recommended Standard Occupational Exposure to Cadmium” H.E.W. Publication Co. (NIOSH), 1976, pp. 76 - 192.

[28] Nirmal Kumar, J.I; Hiren Soni and Rita N. Kumar. Characterization of Metals in Vegetables Using Inductive Coupled Plasma, Journal of Applied Science, Environmental and Management,11 (3), 2007, pp. 75 - 79. www.bioline.org.br/ja.

[29] Okoronko; N, Igwe; J.C, and Onwuchelcua; E.C. Risk and Health Implication of Polluted Soil for Crop Production. American Journal of Biotechnology. 4 (B), 2005, pp. 1521 - 1524.

[30] Rao, L.M and Patnaik, M.S. Heavy Metal Accumulation in Catfish, Mystus vittatus (Bloch) from Mehadrigedda Stream of Vishakhapatnam, Indian Environ Media, 19 (3), 1999, pp. 325 - 329.

[31] Sharma, B.C; Mishra, A.K. and Bhattacharya, K.G. Metal in drinking Water in a Predominantly Rural Area, Indian Journal Environmental Protection, Volume 21 (4), 2000, pp. 315 - 322.

[32] Stroud, K.A and Booth, D.J. Statistical Package, In: Engineering Mathematics WWW. Palgrave.Com / Stroud, Pal grave, GB, London, 5th Edition, 2001, pp. 1130 - 1139.

[33] USEPA. United State Environmental Protection Agency. Quality Criteria for Water. Office of Water Regulation and Standards. Washington DC, 1986, pp. 20460.

[34] Watt, J., Thornton, I., and Cotter, Howells J. Physical Evidence Suggesting the Transfer of Soil Lead $(\mathrm{Pb})$ in to Young Children via Hand to Mouth Activity. Appl. Geoehem, (2): 269 -272, 1994, pp. 15.

[35] Wikipedia. Metal toxicity, In: Free encyclopaedia, Dartmouth Toxic Metal Research - Toxic Metals. June, 2008a.

[36] Wikipedia. Metal Toxicity, In: Announcement: Response to the Advisory Committee on Childhood Lead Poisoning Prevention Report, Low Level Lead Exposure Harms Children: A Reviewed Call for Primary Prevention.CDC. June, 2008b.

[37] Xiong, Z.T. Lead Uptake and Effects on Seed Germination and Plant Growth in a Lead (Pb) Hyper accumulator Brassica pekinensis Rupr. Bulleting of Environmental Contamination and Toxicology, 60, 1998, pp. $285-291$.

\footnotetext{
*Corresponding author.

E-mail address: Halima.mohammedbala@yahoo.com/admuwana@yahoo.com/hamraabatcha@gmail.com/ naslton2002@yahoo.com/abbualiyu@gmail.com
} 